\title{
Characterization of Mutant Aspergillus niger and the Impact on Certain Plants
}

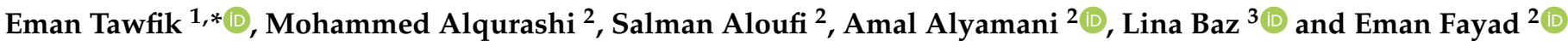 \\ 1 Botany and Microbiology Department, Faculty of Science, Helwan University, Cairo 11795, Egypt \\ 2 Department of Biotechnology, Faculty of Sciences, Taif University, Al-Taif 11099, Saudi Arabia; \\ m.khader@tu.edu.sa (M.A.); s.aloufi@tu.edu.sa (S.A.); a.yamani@tu.edu.sa (A.A.); e.esmail@tu.edu.sa (E.F.) \\ 3 Department of Biochemistry, Faculty of Science-King Abdul Aziz University, Jeddah 21589, Saudi Arabia; \\ Lbaz@kau.edu.sa \\ * Correspondence: emantawfik@science.helwan.edu.eg; Tel.: +20-11-1938-3526
}

check for updates

Citation: Tawfik, E.; Alqurashi, M.; Aloufi, S.; Alyamani, A.; Baz, L.;

Fayad, E. Characterization of Mutant Aspergillus niger and the Impact on Certain Plants. Sustainability 2022, 14, 1936. https://doi.org/10.3390/ su14031936

Academic Editor: Marc A. Rosen

Received: 14 December 2021

Accepted: 29 January 2022

Published: 8 February 2022

Publisher's Note: MDPI stays neutral with regard to jurisdictional claims in published maps and institutional affiliations.

Copyright: (c) 2022 by the authors. Licensee MDPI, Basel, Switzerland. This article is an open access article distributed under the terms and conditions of the Creative Commons Attribution (CC BY) license (https:// creativecommons.org/licenses/by/ $4.0 /)$.

\begin{abstract}
Aspergillus niger is a dangerous pathogen for many plants. It is a major cause of the destruction, rotting and decomposition of plant tissues. Toxicity caused by A. niger can be inhibited by mutation decreasing the destructive effect on plants. An $18 \mathrm{~S}$ rDNA molecular tool was used to identify $A$. niger strains. Sodium azide $\left(\mathrm{NaN}_{3}\right)$ is a chemical mutagen that disturbs fungal enzymatic activity and causes microbial production of cellulose-degrading enzymes, decreasing mycotoxin production. Different concentrations of sodium azide were used to treat $A$. niger $(30,40$ and $50 \mu \mathrm{M})$. The study was designed on two levels: the first level concerned the mutant $A$. niger's mode of action: the higher the mutagen concentration, the lower the growth diameter and spore counts. The mutant $A$. niger's total proteins and flavonoids were reduced when compared to control. RAPD-PCR showed genetic variation in the genetic content of mutant fungi compared to control resulting in a polymorphism percentage of $78.56 \%$. The second level included the effect of these mutants on two plants (onion and maize). The greater the increase in mutant concentration, the greater the increase in the plants' morphological and physiological behavior. In conclusion, mutation reduced fungal activity and strengthened plant resistance.
\end{abstract}

Keywords: Aspergillus niger; Allium cepa L.; Zea mays L.; mutation; sodium azide; genotoxicity; RAPD-PCR; proteins; $18 \mathrm{~S}$ rDNA

\section{Introduction}

Aspergillus niger is used in industrial fermentation for production in several industrial fields, including the food industry. It is used to produce extracellular (food) enzymes, citric acid, for biotransformation and in waste treatment. However, A. niger is a serious plant pathogen and produces many mycotoxins (e.g., ochratoxins and aflatoxins) that contaminant foodstuffs (e.g., groundnut, maize, onion, etc.). Furthermore, $A$. niger causes rotting of vegetables and fruits and causes substantial losses to the economy and agriculture products [1-5]. The fungus reduces seed germination, seedling emergence, and root and shoot elongation, causing mortality at the point of plant emergence [6].

Fungal pathogenicity is related to the mechanism of mycotoxin effect; it allows the fungus to invade the tissue environment and boosts the host's defense lytic activity. Proteinases, lipases, and phospholipases are among the hydrolytic enzymes produced by fungi in culture conditions. These enzymes have a role in fungal pathogenesis and harm the host cells. Fungal nutritional absorption, tissue invasion, and nutrient delivery in a confined environment are all aided by these enzymes [7].

Induced chemical mutation is a technique for creating genetic variation in phytopathogens those results in new strains with varied traits. Induced mutations can be used to provide a new source of resistance to biotic and abiotic stress factors. This enables 
the creation of new resistant varieties [8,9]. Treatment with chemical mutagens can enhance physiological behavior in many plants (e.g., wheat, broad bean) [10].

The chemical mutagen sodium azide $\left(\mathrm{NaN}_{3}\right)$ is one of the most potent mutagens in many phytopathogens. It is used because it is simple and cheap, and it produces mutations that enhance their characteristics. The efficiency of mutant production is influenced by several factors, including azide concentration and treatment time. It causes point mutations and chromosome damage, resulting in plant tolerance to a variety of adverse conditions [8]. At low doses, sodium azide is cytotoxic in a variety of animal and plant systems, inhibiting protein synthesis and replicative DNA synthesis. It has been utilized as a positive control in various systems since it is mutagenic in bacteria, fungi, higher plants, and human cells [9].

The initial goal of the study was to study how mutagens affect fungal growth and physiology (Figure 1). The second goal was to investigate how mutant and control A. niger strains affect specific plants (e.g., maize grains and onion seeds).

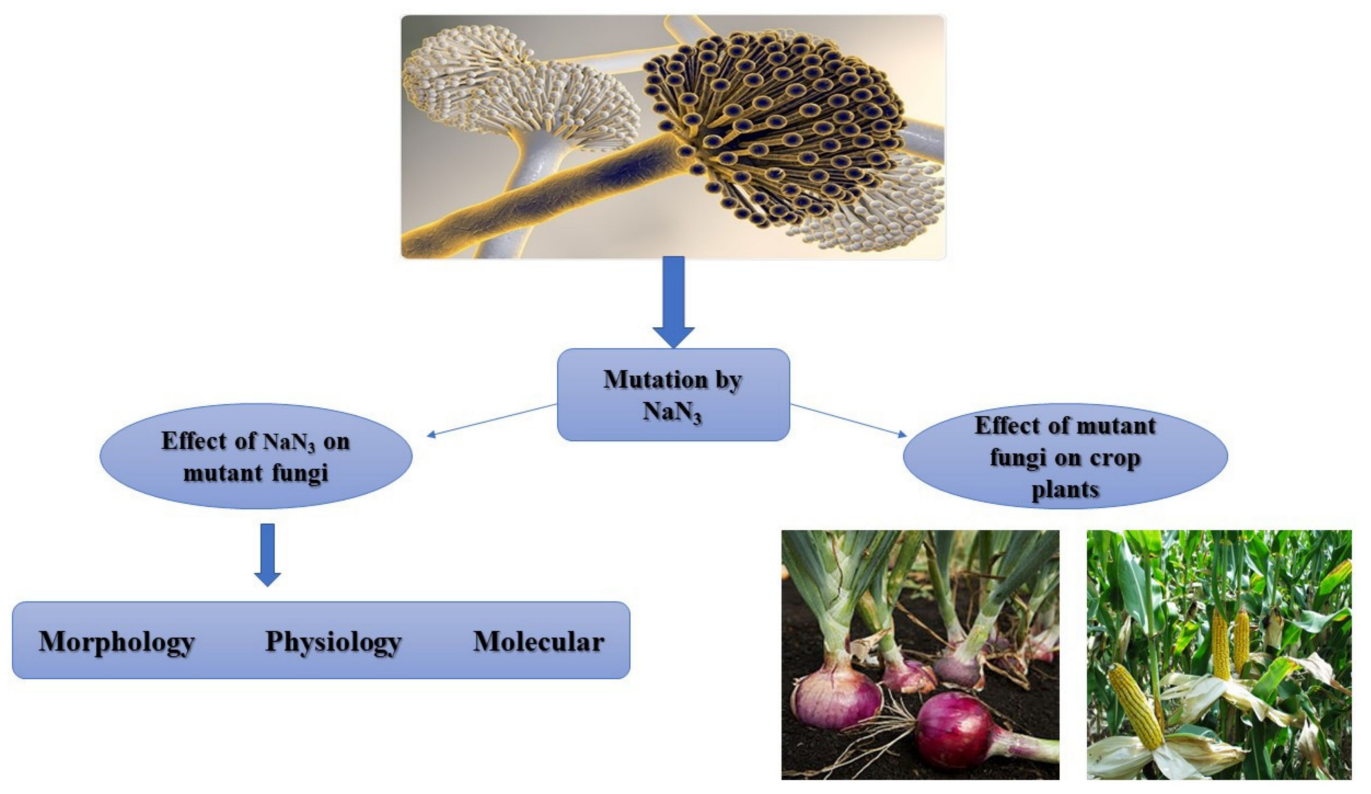

Figure 1. Graphical abstract for work design.

\section{Materials and Methods}

\subsection{Materials}

Aspergillus niger ((Tiegh.): kindly supported by Botany and Microbiology Department, Faculty of Science, Helwan University, Egypt. It was identified molecularly in this study.

Allium cepa L. (Giza-20 var.) seeds and Zea mays L. (Giza-10 var.) grains: purchased from Agricultural Research Center, Giza, Egypt.

\subsection{Molecular Identification of Aspergillus niger}

This was performed using $18 \mathrm{~S}$ rDNA identification for Aspergillus niger. First DNA was extracted by Quick-DNA ${ }^{\mathrm{TM}}$ Fungal/Bacterial Microprep Kit (Zymo research \#D6007, CA, USA) according to the manufacturer's instructions. After that, PCR was applied using Maxima Hot Start PCR Master Mix (Thermo K1051, Waltham, MA, USA) as follows: $25 \mu \mathrm{L}$ of Maxima ${ }^{\circledR}$ Hot Start PCR Master Mix (2X), $1 \mu \mathrm{L}$ of each ITS1 primer, ITS-F:5' TCCGTAGGTGAACCTGCGG-3' ${ }^{\prime}$ and ITS1-R:5'- TTTCGCTGCGTTCTTCATCG-3'” [11]. A $5 \mu \mathrm{L}$ quantity of DNA template $(50 \mathrm{ng} / \mathrm{g}$ ) was made up to $50 \mu \mathrm{L}$ by adding $18 \mu \mathrm{L}$ of water, nuclease-free. PCR was performed using the recommended thermal cycling conditions outlined as follows: initial denaturation for $10 \mathrm{~min}$ at $95^{\circ} \mathrm{C}$, followed by 35 cycles of denaturation for $30 \mathrm{sec}$ at $95^{\circ} \mathrm{C}$, annealing for $60 \mathrm{sec}$ at $57^{\circ} \mathrm{C}$ and extension for $90 \mathrm{sec}$ at $72{ }^{\circ} \mathrm{C}$. The final extension correction step was at $72{ }^{\circ} \mathrm{C}$ for $10 \mathrm{~min}$. Then PCR cleanup was 
performed to the PCR product using the GeneJET ${ }^{\mathrm{TM}}$ PCR Purification Kit (Thermo K0701, Waltham, MA, USA) according to the manufacturer's instructions.

Finally, sequencing of the PCR product was performed using the GATC Company ABI 3730xl DNA sequencer using forward and reverse primers according to the new 454 technology.

\subsection{Preparation of Mutagen Solutions of Sodium Azide}

Three different concentrations of sodium azide (Granular, Reagent, 39H015) were prepared (30, 40 and $50 \mu \mathrm{M})$ and a control solution (without mutagen) [12]. An amount of $50 \mu \mathrm{L}$ of each concentration was poured into $50 \mathrm{~mL}$ PDA media plates.

\subsection{Impact of Sodium azide}

The main aim of this study was to estimate the effect of sodium azide mutagen on the morphological and physiological behavior of $A$. niger. After that, some crops were treated with the mutant fungi with others subject to a control condition, and the effects on the crops were evaluated. The impact of sodium azide mutagen was estimated at two levels:

Effect of mutagen on Aspergillus niger (direct evaluation).

Effect of these mutant and control A. niger on both Zea mays L. and Allium cepa L. (indirect evaluation).

\subsubsection{Direct Evaluation}

Fungal Isolates Preparation and Inoculation

The mycelium of $A$. niger isolates were inoculated in PDA plates $(200 \mathrm{~g}$ potato extract, $20 \mathrm{~g}$ dextrose and $20 \mathrm{~g}$ agar $/ \mathrm{L}$ ) and incubated for 5 days at $28^{\circ} \mathrm{C}$ for growth.

For the PDA plates, $50 \mu \mathrm{L}$ of each mutagen concentration $(30,40,50 \mu \mathrm{M})$ were inoculated in sterile Petri-dishes. Then sterile PDA medium was poured over them with rotation for homogenous distribution of the mutagen. After that, a fungal disc was inoculated in each plate compared to control. The plates were incubated for 5 days at $28^{\circ} \mathrm{C}$ for growth.

For potato dextrose broth tubes, thirty microliters of each mutagen concentration were inoculated in falcon tubes containing potato dextrose broth media. These tubes were incubated for 5 days at $28^{\circ} \mathrm{C}$ at $150 \mathrm{rpm}$ for growth.

\section{Morphological and Microscopic Examination of Mutant Fungal Spores}

The growth of the inoculated fungal discs affected by different sodium azide concentrations compared to control was observed. A fungal disc (cut with $0.5 \mathrm{~cm}$ cork pourer) was removed into a test tube containing $10 \mathrm{~mL}$ of sterile $\mathrm{dH}_{2} \mathrm{O}$ and thoroughly checked. The spores germinated from the mutant fungi were examined under a microscope.

Physiological Parameters of Mutant Fungi

(1) $\mathrm{pH}$ of Broth Media

The $\mathrm{pH}$ of the nutrient broth medium was measured using a JENWAY $3510 \mathrm{pH}$ meter. This was measured to estimate the effect of the different $\mathrm{NaN}_{3}$ concentrations on the growth media of A. niger.

\section{(2) Total Protein of A. niger}

The total protein was extracted from fungal mats according to Bradford [13] as follows: A half $g$ was weighted and ground with liquid nitrogen. Then $500 \mu \mathrm{L}$ of $2 x$ protein buffer (1 M Tris - $\mathrm{HCl}$ (pH 8.8), $0.25 \mathrm{mM}$ EDTA, $10 \%$ SDS, $50 \%$ glycerol) was added for each sample. Finally, the four samples were centrifuged at $21,952 \times g$ at $4{ }^{\circ} \mathrm{C}$ and the supernatants were transferred into new tubes. Protein concentration was estimated as follows: $0.1 \mathrm{~mL}$ of supernatant was transferred using a pipette into a test tube and $5 \mathrm{~mL}$ of protein reagent was added (100 mg Coomassie Brilliant Blue G-250 dissolved in $50 \mathrm{~mL}$ 95\% ethanol, then 85\% phosphoric acid was added and made up to $1 \mathrm{~L}$ with $\mathrm{dH}_{2} \mathrm{O}$ ). The samples were mixed with the reagent and measured by spectrophotometer at wavelength $595 \mathrm{~nm}$. The concentration 
of protein was determined according to the protein standard curve. The concentration was calculated according to the equation for standard curve calibration [14]:

$$
X=\frac{Y-0.030}{0.007}
$$

$X$ : concentration, $Y$ : absorbance at $595 \mathrm{~nm}$

(3) Total Flavonoids of $A$. niger

Total flavonoid content of the $A$. niger extract was determined using aluminum chloride colorimetric assay [15] as follows: Half $\mathrm{mL}$ of the extract was added to $150 \mu \mathrm{L}$ of $5 \% \mathrm{NaNO}_{3}$ and allowed to stand for $6 \mathrm{~min}$. Then $150 \mu \mathrm{L}$ of $10 \% \mathrm{AlCl}_{3}$ solution was added and allowed to stand for $6 \mathrm{~min}$, after which $200 \mu \mathrm{L}$ solution of $1 \mathrm{M} \mathrm{NaOH}$ was added; then the mixture was made up to $5 \mathrm{~mL}$ with methanol and mixed well. After incubation for $15 \mathrm{~min}$, the absorbance was measured spectrophotometrically against a blank at $510 \mathrm{~nm}$. The total flavonoid content was expressed in milligrams of quercetin equivalents (QE) per gram extract (mg QE/g). The standard curve of quercetin was used for calculation of total flavonoids.

The total flavonoid content was calculated according to the following equation:

$$
X=\frac{(R-B) * \text { dilution factor } * \text { factor }}{1000}
$$

*X: concentration $(\mathrm{mg} / \mathrm{g}), R$ : samples absorbance, $B$ blank absorbance

(4) DNA Isolation and Molecular Marker (RAPD-PCR)

The total genomic DNA of mutant $A$. niger was isolated using Doyle and Doyle's [16] CTAB method as follows: Half g of fungal mat was ground in $700 \mu \mathrm{L}$ of $2 \%$ CTAB buffer and incubated for $30 \mathrm{~min}$ at $65^{\circ} \mathrm{C}$ with vertexing every $10 \mathrm{~min}$. The supernatant was transferred into new Eppendorf tubes after centrifugation at $16,128 \times \mathrm{g}$ for $10 \mathrm{~min}$. Each tube was filled with an equal volume of chloroform: isoamyl alcohol (24:1) and allowed to sit for $2 \mathrm{~min}$ at room temperature before being centrifuged at $16,128 \times \mathrm{g}$ for $10 \mathrm{~min}$ at $4{ }^{\circ} \mathrm{C}$. The upper aqueous layer was transferred to new tubes, which were then filled with $800 \mu \mathrm{L}$ of ice-cold absolute ethanol and stored at $-20{ }^{\circ} \mathrm{C}$ for approximately $2 \mathrm{~h}$. The solution was centrifuged to obtain DNA pellets, which were then washed in $70 \%$ ice-cold ethanol. Finally, the pellets were resuspended in $50 \mu \mathrm{L}$ TE buffer and stored at $-20{ }^{\circ} \mathrm{C}$ until the RAPD-PCR reaction was performed.

For RAPD-PCR bioassay, seven RAPD decamers were used, and the results were consistent and clear. In the tables, a list of primers is shown (in Results section). The RAPD-PCR reaction was carried out in a Biometra thermocycler. The reaction mixture contained $12.5 \mu \mathrm{L}$ Taq master mix (COSMO PCR RED M. Mix, W1020300x), $2 \mu \mathrm{L}$ genomic DNA, and $1 \mu \mathrm{L}$ for

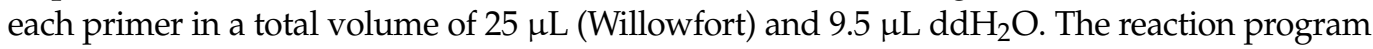
consisted of 35 cycles of denaturation for $30 \mathrm{~s}$ at $94^{\circ} \mathrm{C}$, annealing for $30 \mathrm{~s}$ at different degrees for each primer, as shown in tables, and extension for $1 \mathrm{~min}$ at $72^{\circ} \mathrm{C}$. After that, one step of final extension at $72{ }^{\circ} \mathrm{C}$ for $10 \mathrm{~min}$ was followed by cooling at $4{ }^{\circ} \mathrm{C}$. On a $1.4 \%$ agarose gel, the amplified PCR product was evaluated using a Willofort, BERUS $100 \mathrm{bp}$ DNA ladder.

\subsubsection{Indirect Evaluation}

Plant Germination and Infection

Seeds and grains of both plants (A. cepa and Z. mays) were geminated in Petri-dishes with filter papers. There were ten seeds in each plate with 5 replicates. In addition, plant seeds were germinated in pots. Ten seeds were sown in each pot with five pots selected for infection with mutant fungi (-ve control, +ve control, 30, 40 and $50 \mu \mathrm{M}$ ). One milliliter (1100 spores $/ \mathrm{mL}$ ) of each mutant fungus was used for the inoculation of different plant seeds. One germination test was applied as a negative control, in which the seed germinated without 
any fungal infection. The positive control involved seeds infected with non-mutant $A$. niger. The germinated seeds and grains were incubated at room temperature for two weeks.

\section{Morphological Measurements}

After ten days of germination, the fresh weight and shoot length were measured and the percentage loss in seedling parameters were estimated compared to controls. The general effect on plant growth behavior was estimated from seedlings germinated in pots and infected with different mutant $A$. niger compared to positive and negative control as previously mentioned.

Physiological Measurements of plants infected with mutant fungi

\section{(1) Total proteins}

The total protein was extracted according to [12] as follows: An amount of $0.5 \mathrm{~g}$ of leaves was weighed and ground thoroughly with $0.5 \mathrm{~mL}$ of $[2 \times]$ buffer. Then the mixture was vortexed for $10 \mathrm{~min}$ and centrifuged for $15 \mathrm{~min}$ at $21,952 \times g$ at $4^{\circ} \mathrm{C}$. The supernatant contained the total protein content of the plant species. Finally, the protein concentration was estimated according to [12] as follows: $0.1 \mathrm{~mL}$ of supernatant was pipetted into a test tube and $5 \mathrm{~mL}$ of protein reagent was added, mixed, and measured by spectrophotometer at wavelength $595 \mathrm{~nm}$. The concentration of protein was determined from the protein standard curve. The concentration was calculated according to the following equation [13]:

$$
X=\frac{Y-0.030}{0.007}
$$

\section{(2) Total flavonoids}

Total flavonoid content of both $A$. cepa and Z. mays extract was determined using aluminum chloride colorimetric assay [15] as follows: Half $\mathrm{ml}$ of the extract was added to $150 \mu \mathrm{L}$ of $5 \% \mathrm{NaNO}_{3}$ and allowed to stand for $6 \mathrm{~min}$. Then $150 \mu \mathrm{L}$ of $10 \% \mathrm{AlCl}_{3}$ solution was added and allowed to stand for $6 \mathrm{~min}$, after which $200 \mu \mathrm{L}$ solution of $1 \mathrm{M} \mathrm{NaOH}$ was added; then the mixture was completed to $5 \mathrm{~mL}$ with methanol and mixed well. After incubation for $15 \mathrm{~min}$, the absorbance was measured spectrophotometrically against a blank at $510 \mathrm{~nm}$. The total flavonoid content was expressed in milligrams of quercetin equivalents $(\mathrm{QE})$ per gram extract $(\mathrm{mg} \mathrm{QE} / \mathrm{g})$. The standard curve of quercetin was used for calculation of total flavonoids.

The total flavonoid content was estimated according to the following equation:

$$
X=\frac{(R-B) * \text { dilution factor } * \text { factor }}{1000}
$$

${ }^{*} X$ : concentration $(\mathrm{mg} / \mathrm{g}), R$ : samples absorbance, $B$ : blank absorbance

\subsection{Statistical Analysis}

The presence of a band was coded as 1, while the absence of a band was coded as 0 . The images obtained from gel electrophoresis were analyzed, and the presence of a band was coded as 1 . After generating a pairwise similarity matrix using Jaccard's similarity coefficient, the unweighted pair group method with the arithmetic averaging algorithm (UPGMA) was used to develop a dendrogram. Bio-Rad Quantity (4.6.2) (Dubai Biotechnology and Research Park (DUBIOTECH)) was used to perform these calculations [17].

The statistical analysis for the morphological and physiological data were performed using SPSS 21 (IBM, USA). The data was subjected to analysis of variance. Standard deviations and means were calculated.

\section{Results}

Different sodium azide mutagen concentrations were prepared to affect the bioactivity of Aspergillus niger. This included different morphological, physiological, and molecular 
parameters of $A$. niger. In addition, the effect of these mutant fungi on the activity of both A. cepa and Z. may was assessed.

\subsection{Molecular Identification of Aspergillus Niger}

The molecular identification results obtained from $18 \mathrm{~S}$ rDNA and sequencing showed that the tested fungus was Aspergillus niger (lcl I Query_20417) (Figure 2). The tree obtained from the alignment results, obtained from the NCBI data base, showed that the provided specimen was A. niger which had $100 \%$ identity with Aspergillus niger strain URM7014 18S ribosomal RNA gene, partial sequence; internal transcribed spacer 1, 5.8S ribosomal RNA gene, and internal transcribed spacer 2, complete sequence; and $28 \mathrm{~S}$ ribosomal RNA gene, partial sequence.

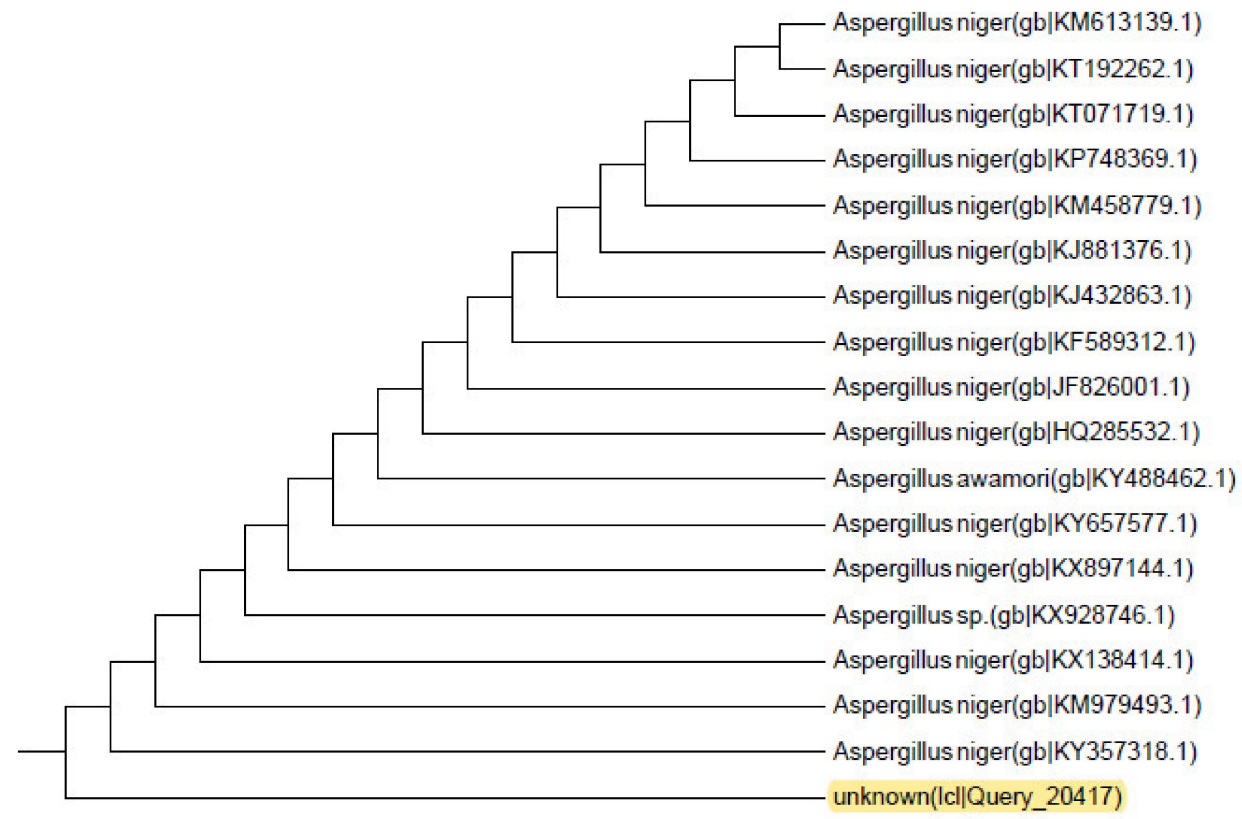

Figure 2. Phylogenetic tree based on $18 \mathrm{~S}$ rDNA identification with ITS1 primers. showing the relation of the target sample to other Aspergillus niger strains.

\subsection{Direct Evaluation for Mutant Fungi}

\subsubsection{Morphology of Fungi and Their Spores}

The mutant $A$. niger growth diameter was estimate manually. The results (Table 1 ) indicated that the growth diameter of $A$. niger decreased with increase in sodium azide concentration compared to control. For spore suspension, the examined spores of mutant A. niger showed spore inhibition in comparison to control.

Table 1. Growth diameter and spore inhibition of mutant $A$. niger treated with sodium azide.

\begin{tabular}{ccccc}
\hline & Control & $\mathbf{3 0} \boldsymbol{\mu \mathbf { M }}$ & $\mathbf{4 0} \boldsymbol{\mu \mathbf { M }}$ & $\mathbf{5 0} \boldsymbol{\mu \mathbf { M }}$ \\
\hline Growth diameter, $\mathrm{cm}$ & $7.76 \pm 0.25$ & $1.73 \pm 0.15$ & $1.10 \pm 0.10$ & $0.78 \pm 0.27$ \\
Spores count, spore $/ \mathrm{mL}$ & $93.66 \pm 5.68$ & $47.00 \pm 11.00$ & $30.33 \pm 3.05$ & $22.66 \pm 4.04$ \\
\hline
\end{tabular}

\subsubsection{Physiological Parameters of Mutant Fungi}

The measured physiological parameters of mutant $A$. niger compared to control included $\mathrm{pH}$ of culture media, total protein of fungi and total flavonoids (from both fungal extract and media). The variation of these physiological parameters was estimated for mutant fungi compared to control (Table 2). All the physiological parameters showed significant differences between the different strains. 
Table 2. Some physiological parameters of $A$. niger in response to sodium azide.

\begin{tabular}{cccccc}
\hline & Control & $\mathbf{3 0} \boldsymbol{\mu \mathbf { M }}$ & $\mathbf{4 0} \boldsymbol{\mu M}$ & $\mathbf{5 0} \boldsymbol{\mu M}$ & $p$-Value \\
\hline $\begin{array}{c}\mathrm{pH} \text { of media } \\
\text { Total protein "mg/g" }\end{array}$ & $5.21 \pm 0.34$ & $5.65 \pm 0.02$ & $5.48 \pm 0.26$ & $5.74 \pm 0.01$ & $0.002^{* *}$ \\
$\begin{array}{c}\text { Total flavonoids "mg/g" } \\
\text { (fungi) }\end{array}$ & $20.61 \pm 0.47$ & $10.45 \pm 0.43$ & $15.49 \pm 0.47$ & $12.38 \pm 0.58$ & $0.008^{* *}$ \\
$\begin{array}{c}\text { Total flavonoids "mg/g" } \\
\text { (media) }\end{array}$ & $61.04 \pm 0.08$ & $42.70 \pm 0.93$ & $47.40 \pm 0.98$ & $43.48 \pm 0.74$ & $0.009^{* *}$ \\
\hline
\end{tabular}

* Significant; ** highly significant.

For $\mathrm{pH}$ of medium, the original $\mathrm{pH}$ of the negative control medium (medium only without fungal inoculum nor mutagen) was 6.23. When the medium was inoculated with mutant fungi, the $\mathrm{pH}$ decreased because of different secretions of the mutant fungi. However, compared to control, $\mathrm{pH}$ increased when the mutagen concentration increasesd. The highest $\mathrm{pH}$ value was for the sodium azide treatment of $50 \mu \mathrm{M}$. The total fungal proteins increased in mutants compared to control. Otherwise, in $50 \mu \mathrm{M}$, the proteins were inhibited to be less than the control. The total flavonoid exosecretion in the medium was higher than the endosecretion within fungal cells. However, generally they decreased in mutants compared to control. Except in $40 \mu \mathrm{M}$ treatments in comparison to other treatments, it was higher for 30 and $50 \mu \mathrm{M}$. Generally, there was no definite characterization for the physiological parameters of fungi as they sometimes increased, and at other times decreased in response to mutagen treatment.

\subsubsection{Molecular Variation}

The genomic DNA of control and different mutant $A$. niger strains was isolated from fungal mats in broth media to be used in RAPD-PCR bioassay which was performed using 5 oligonucleotide RAPD primers. Only 3 of them gave reproducible bands. These primers were OPA-12, OPB-17 and OPZ-07 (Table 3), with P4 and RFU-25 not producing clear bands. A total of 19 different bands were obtained from these primers. Their data are listed and illustrated in Figure 3.

Table 3. RAPD primer data and polymorphism percentage.

\begin{tabular}{|c|c|c|c|c|}
\hline Primer Code & Primer Sequence & $\mathrm{GC} \%$ & $\operatorname{Tm}$ & Polymorphism \% \\
\hline OPB-17 & $5^{\prime}$-AGGGAACGAG-3' & 60 & 33.1 & 66.66 \\
\hline OPA-12 & 5'-TCGGCGATAG-3' & 60 & 34 & 85.7 \\
\hline OPZ-07 & $5^{\prime}$-CCAGGAGGAC-3' & 70 & 34.6 & 83.33 \\
\hline \multicolumn{4}{|c|}{ Total polymorphism percentage (\%) } & 78.56 \\
\hline
\end{tabular}

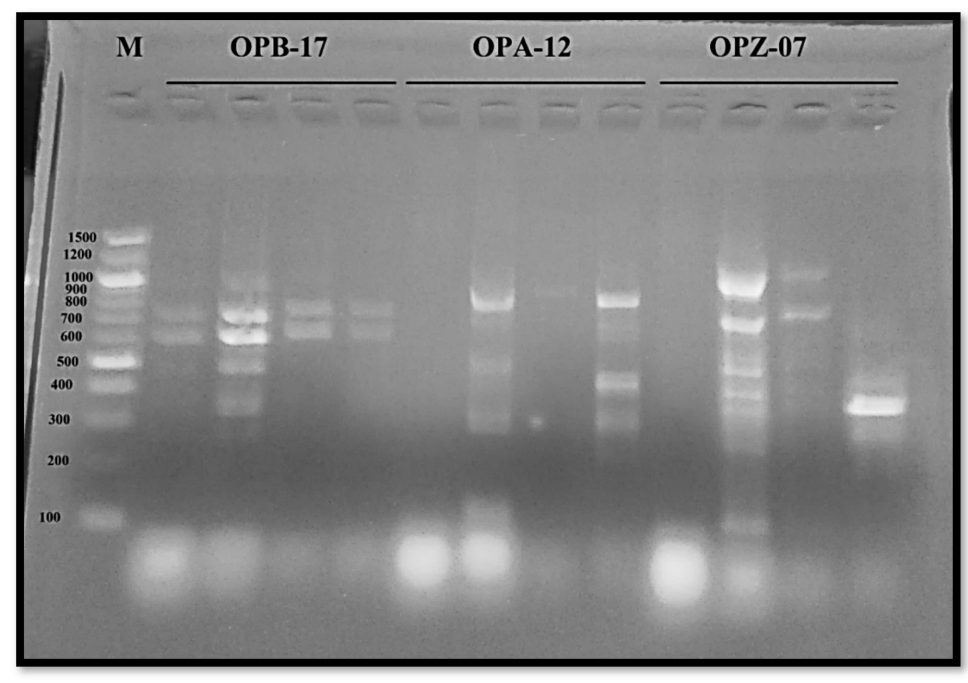

Figure 3. Agarose gel electrophoresis for RAPD-PCR of mutant $A$. niger with control. For each primer, the samples were arranged as follows: control: non-mutant $A$. niger; $30 \mu \mathrm{M}$ : mutant $A$. niger with $30 \mu \mathrm{M}$ sodium azide; $40 \mathrm{mM}$ : mutant $A$. niger with $40 \mathrm{mM}$ sodium azide; $50 \mu \mathrm{M}$ : mutant $A$. niger with $50 \mu \mathrm{M}$ sodium azide. 
The total similarity matrix resulting from these mutants is shown in Table 4 . The matrix shows that the mutant $A$. niger $(50 \mathrm{mM})$ was genetically close to the control. The $40 \mathrm{mM}$ mutant was very distant and occupied a separate clade.

Table 4. Total similarity matrix based on all RAPD-PCR primers using BioRad Quantity One software.

\begin{tabular}{ccccc}
\hline & Control & $\mathbf{3 0} \boldsymbol{\mu M}$ & $\mathbf{4 0} \boldsymbol{\mu M}$ & $\mathbf{5 0} \boldsymbol{\mu M}$ \\
\hline Control & 100 & 24.23 & 25.87 & 36.87 \\
$30 \mu \mathrm{M}$ & 24.23 & 100 & 16.5 & 31.27 \\
$40 \mu \mathrm{M}$ & 25.87 & 16.5 & 100 & 17.8 \\
$50 \mu \mathrm{M}$ & 36.87 & 31.27 & 17.8 & 100 \\
\hline
\end{tabular}

Figure 4 represents a total dendrogram based on morphological, physiological, and molecular data. It illustrates that both the control and the $30 \mathrm{mM}$ mutant were relatively close to each other. However, the dendrogram also confirms the separation of the $40 \mathrm{mM}$ mutant in a separate clade.

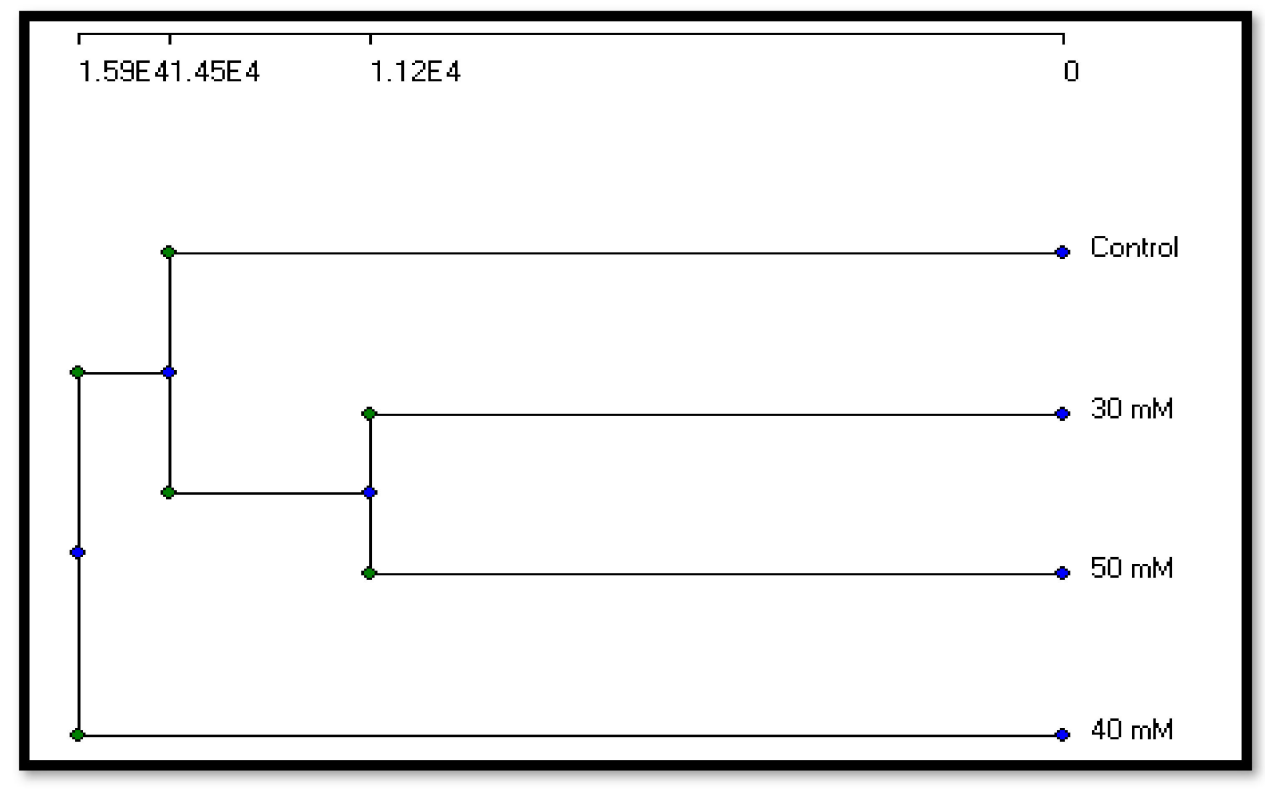

Figure 4. Dendrogram based on total parameters (morphology, physiology and molecular) for A. niger mutants using Community Analysis Package (CAP software).

\subsection{Indirect Evaluation of Plants Infected with Mutant Fungi}

This section explains the effect of different mutants and control A. niger on two plants. Morphological and physiological parameters were estimated for two plants: A. cepa and Z. mays.

\subsubsection{Morphological Parameters and Seed Germination of Infected Plants}

Two different plants were tested for resistance of $A$. niger. Both A. cepa and Z. mays showed gradient resistant to mutant treatments of $A$. niger compared to the positive control. The results are illustrated in Table 5 and Figure $5 \mathrm{a}, \mathrm{b}$ for $A$. cepa and Z. mays, respectively. The results showed that the pot experiment of germinated plant seeds infected with different mutations and controls of $A$. niger showed a loss in the total measure $\%$ when compared to controls (for before and after measurements). All these results indicated and confirmed the following: when the mutant concentration increased in $A$. niger, this had a negative effect on the fungi but positive effects on the infected plants. This means that plants were more resistant to the mutant fungi compared to the +ve control. The infection symptoms were more obvious in plants infected with the +ve control $A$. niger rather than mutant fungi. All this is a reflection of the inhibitory effect of sodium azide on A. niger. 
Table 5. Plant morphological and seed germination responses to infection with the sodium azide mutant $A$. niger.

\begin{tabular}{|c|c|c|c|c|c|c|c|}
\hline Plant & Mutants & $\begin{array}{l}\text { Fresh Weight } \\
\text { Loss \% }\end{array}$ & F-Value & $\begin{array}{l}\text { Shoot Length } \\
\text { Loss } \%\end{array}$ & F-Value & $\begin{array}{c}\text { Seed Germination } \\
\text { Loss } \%\end{array}$ & F-Value \\
\hline \multirow{5}{*}{ Zea mays } & - Ve Control & $0.00 \pm 0.00$ & \multirow{5}{*}{$136.32 * * *$} & $0.00 \pm 0.00$ & \multirow{5}{*}{$93.56^{* * *}$} & $0.00 \pm 0.00$ & \multirow{5}{*}{$306.67^{* * *}$} \\
\hline & +Ve Control & $80.3 \pm 2.34$ & & $54.2 \pm 2.14$ & & $93.5 \pm 9.2$ & \\
\hline & $30 \mu \mathrm{M}$ & $50.5 \pm 2.17$ & & $37.3 \pm 1.24$ & & $47.5 \pm 4.2$ & \\
\hline & $40 \mu \mathrm{M}$ & $26.4 \pm 2.11$ & & $30.2 \pm 1.11$ & & $33.3 \pm 1.4$ & \\
\hline & $50 \mu \mathrm{M}$ & $12.5 \pm 0.89$ & & $15.7 \pm 0.52$ & & $20.2 \pm 1.1$ & \\
\hline \multirow{5}{*}{ Allium сера } & - Ve Control & $0.00 \pm 0.00$ & \multirow{5}{*}{$122.67^{* * *}$} & $0.00 \pm 0.00$ & \multirow{5}{*}{$110.33^{* * *}$} & $0.00 \pm 0.00$ & \multirow{5}{*}{$197.33^{* * *}$} \\
\hline & + Ve Control & $86.3 \pm 5.67$ & & $79.7 \pm 5.47$ & & $91.7 \pm 9.25$ & \\
\hline & $30 \mu \mathrm{M}$ & $59.7 \pm 2.45$ & & $47.5 \pm 3.33$ & & $67.7 \pm 8.33$ & \\
\hline & $40 \mu \mathrm{M}$ & $42.5 \pm 2.11$ & & $36.3 \pm 1.27$ & & $29.3 \pm 3.29$ & \\
\hline & $50 \mu \mathrm{M}$ & $23.7 \pm 1.57$ & & $22.9 \pm 1.15$ & & $11.6 \pm 0.77$ & \\
\hline
\end{tabular}

*** highly significant. - Ve control: plants without fungal treatment, +Ve control: plants infected with non-mutant A. niger, $30 \mu \mathrm{M}$ : plants infected with mutant $\mathrm{A}$. niger with $30 \mu \mathrm{M}$ sodium azide, $40 \mathrm{mM}$ : plants infected with mutant A. niger with $40 \mu \mathrm{M}$ sodium azide, $50 \mu \mathrm{M}$ : plants infected with mutant $A$. niger with $50 \mu \mathrm{M}$ sodium azide.

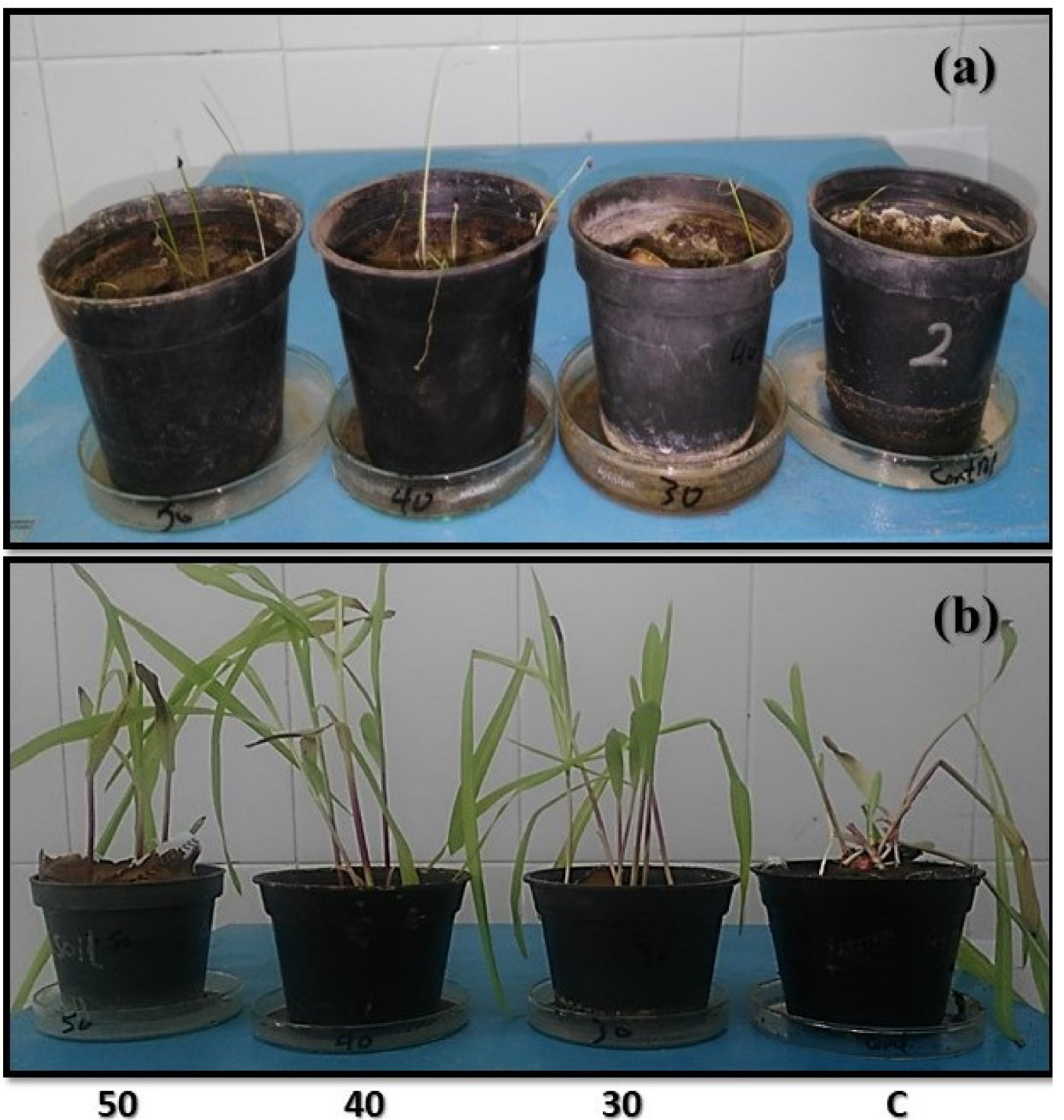

Figure 5. Pot experiment of plants. (a) Allium cepa infected with mutants and control A. niger. (b) Zea mays infected with mutants and control $A$. niger. The concentrations were: C: control treatment (non-mutant), $30 \mu \mathrm{M}, 40 \mu \mathrm{M}, 50 \mu \mathrm{M}$ sodium azide mutagen. 


\subsubsection{Physiological Parameters of Infected Plants}

Total proteins and total flavonoids of mutant $A$. niger-infected A. cepa and Z. mays were quantified and compared to control. In terms of total proteins, the higher the mutant concentration in $A$. niger, the higher the total protein content of these plants. This suggests that sodium azide reduces $A$. niger's impact while increasing plant resilience. Table 6 depicts these findings.

Table 6. The total proteins of plants infected with mutant $A$. niger.

\begin{tabular}{cccccc}
\hline \multirow{2}{*}{ Plant } & \multirow{2}{*}{ Mutants } & \multicolumn{2}{c}{ Proteins } & \multicolumn{2}{c}{ Flavonoids } \\
\cline { 2 - 5 } & & Mean & F-Value & Mean & F-Value \\
\hline \multirow{4}{*}{ Zea mays } & - Ve Control & $49.54 \pm 0.37$ & & & \\
& + Ve Control & $14.33 \pm 0.35$ & & $0.073 \pm 0.004$ & \\
& $30 \mu \mathrm{M}$ & $23.28 \pm 2.10$ & $298.799 * * *$ & $0.065 \pm 0.005$ & \multirow{2}{*}{$246.315^{* * *}$} \\
& $40 \mu \mathrm{M}$ & $36.09 \pm 0.81$ & & $0.144 \pm 0.006$ & \\
& $50 \mu \mathrm{M}$ & $38.90 \pm 0.217$ & & $0.158 \pm 0.003$ & \\
\multirow{4}{*}{ Allium cepa } & - Ve Control & $28.26 \pm 0.39$ & & & \\
& + Ve Control & $2.38 \pm 0.21$ & & $0.057 \pm 0.002$ & \\
& $30 \mu \mathrm{M}$ & $5.19 \pm 0.21$ & $77.138^{* * *}$ & $0.064 \pm 0.002$ & \multirow{2}{*}{$0.089 \pm 0.005$} \\
& $40 \mu \mathrm{M}$ & $6.85 \pm 0.37$ & & $0.097 \pm 0.002$ & \\
\hline
\end{tabular}

*** highly significant. -Ve control: plants without fungal treatment, +Ve control: plants infected with non-mutant A. niger, $30 \mu \mathrm{M}$ : plants infected with mutant $A$. niger with $30 \mu \mathrm{M}$ sodium azide, $40 \mu \mathrm{M}$ : plants infected with mutant A. niger with $40 \mu \mathrm{M}$ sodium azide, $50 \mu \mathrm{M}$ : plants infected with mutant $A$. niger with $50 \mu \mathrm{M}$ sodium azide.

For total flavonoids, the greater the increase in mutant concentration in A. niger, the greater the decrease in total flavonoids in these plants. This means that sodium azide had a negative effect on $A$. niger, while positively affecting the plants and enhancing resistance in the plants. This may be explained as follows: the plants secret more secondary metabolites (e.g, flavonoids) to resist the different mycotoxins secreted by fungi. All these results are illustrated in Table 6. Flavonoids are structurally varied secondary metabolites that serve a variety of roles in plants. These include roles in plant development, pigmentation, and UV protection, as well as a variety of defense and signaling functions between plants and microbes.

\section{Discussion}

The main purpose of choosing A. niger for this study is that it produces organic acids, enzymes, plant growth regulators, mycotoxins, and antibiotics. Under normal conditions, A. niger may create certain enzymes and is a prolific exporter of homologous protein species.

Pathogenic fungi secrete enzymes which are integral to their pathogenesis. The A. niger group is composed of black-spored Aspergillus species. The spores are responsible for secretion of several secondary metabolites, known as mycotoxins. A. niger is widely distributed in many habitats; it has not only been isolated from host cells but was recognized and isolated from space [18]. Molecular identification was used to define A. niger isolates collected from U.S. segment surfaces of the International Space Station. According to Shankar [3] and Zohri et al. [7], the fungal secretions are virulent factors of fungi to facilitate the adherence and hydrolysis of the components of the cells of the host. Schuster et al. [1] examined the idea that $A$. niger strains produce mycotoxins (e.g., aflatoxins, ephrotoxic and carcinogenic mycotoxin ochratoxin A). They suggested that these toxins were produced under uncontrolled storage conditions for $A$. niger. In addition, [2] demonstrated that $A$. niger isolates are responsible for production of mycotoxins that affect food grade enzymes. Soares et al. [19] reported the infection of maize with A. niger which produced fumonisin B2 and ochratoxin A, while [20] found that mycotoxins, such as ochratoxins, could be isolated from grapes infected by $A$. niger and $A$. carbonarius strains.

In this study, spore count, and fungal growth were negatively affected as mutagen concentration increased. Fungal spores are important as causes of disease, pollution, and 
as biological warfare agents. Dijksterhuis and Samson [21] demonstrated that spores have several advantages over their vegetative counterparts. Spores have unique characteristics, such as tolerance to extreme temperatures, poisonous chemicals, desiccation, and radiation, among others. So, in this study it was essential to estimate the spore count to evaluate any changes due to exposure to mutation. The germination and count of spores varied in response to mutation according to this study.

Kumar and Parikh [22] suggested that change in fungal growth diameter could be explained as a result of chemical mutagens causing the production of cellulose-degrading enzymes and inhibiting extracellular protein production in fungi which inhibits fungal cell wall formation.

To prevent spore germination, sodium azide was added to the bioconversion medium. Spores could be used as a catalyst in the bioconversion of glucose to gluconic acid because of these treatments [23]. Sodium azide, either as the free acid $\mathrm{HN}_{3}$, or as an ionic compound, binds metal sites in enzymes. The azide anion acts as a reversible or irreversible inhibitor of catalytic hemoproteins, such as catalase and horseradish peroxidase, in various situations. In previous studies, sodium azide was used as the bioconversion medium. Its effect on the enzyme was compared to that of commercial glucose oxidase because it was found to be toxic. When sodium azide was added to the bioconversion medium containing commercial glucose oxidase, 50\% of the activity was lost when compared to the control [23]. As a result, sodium azide was discovered to be a glucose oxidase enzyme inhibitor. There have been reports that sodium azide inhibits peroxidase and laccase [24,25]. With $A$. niger, a sodium azide mutagen was used; [26] worked on $A$. niger mutants to increase glucose oxidase enzyme production.

For the physiological parameters, this study showed that mutation causes variation in responses and indicated that a concentration of $40 \mu \mathrm{M}$ sodium azide has a better response rather than the other two concentrations. These findings could be explained by [27-29] who concluded that many enzymes, including invertase and galactosidase, are found in Aspergillus spp. Aflatoxigenic and probable aflatoxin makers, Aspergillus spp., infect maize, peanuts, and tree nuts. Chemical (sodium azide, ethyl methane sulphonates, and nitrous acid) and physical (ultraviolet radiation) mutagens have a significant impact on them. Aflatoxigenic fungi contaminate food, hence mutation can be utilized to eliminate this impact.

The present study found that mutation caused genotoxicity and instability in DNA content. Other studies have also found this, using molecular markers to estimate the variation caused by mutations. Many researchers [30-32] have shown that molecular markers, such as inter-simple sequence repeats (ISSRs), random-amplified polymorphic DNA (RAPD), and amplified fragment length polymorphisms (AFLPs) are three DNA profiling approaches that can be effectively utilized to assess genetic diversity. They are dominant markers that use anonymous regions enabling study of genomic diversity using universal primers. All these approaches were related to this investigation which used RAPD-PCR as a molecular technique to estimate the genetic diversity in A. niger resulting from exposure to the sodium azide mutagen. Similar results from chemical mutagenic treatments of the strain could predict the activation of specific genes because of mutant mutations. According to [33] a mutation caused aflR overexpression in A. flavus, which increased aflatoxin pathway gene transcription and aflatoxin accumulation.

The evolutionary history of a pathogen population determines the genetic makeup of that population. Genetic makeup data is thought to provide insight into the evolutionary potential of disease populations in the future. The distribution and amount of genetic variability among and within populations is referred to as genetic structure. The genetic makeup includes both genotype and gene diversity. Gene diversity refers to the number and frequencies of alleles at particular loci in a population, whereas genotype diversity refers to the number and frequencies of multi-locus genotypes in a population [34,35].

In this study, both Z. maize and $A$. cepa showed high resistance, in morphological and physiological parameters, in response to mutant $A$. niger strains compared to control. This agrees with [36] who identified three fungal species that infect maize, Aspergillus flavus, 
Aspergillus niger and Fusarium spp. These species have inhibitory effects on maize with percentage reductions of 42, 96 and 13\%. Moreover, [37] found that ten fungal endophytes of maize cause severe diseases in maize.

\section{Conclusions}

Aspergillus niger is a common phytopathogen which infects many fruits and vegetables, such as onion, maize and others. A. niger was molecularly identified using $18 \mathrm{~S}$ rDNA. Sodium azide is a chemical mutagen that inhibits fungal enzymatic activity and as a result decreases mycotoxin production. Different concentrations of sodium azide were used to treat and inhibit the vital activities of $A$. niger. The study was divided into two parts: the manner of action of mutagen concentrations on $A$. niger, and the infection by these mutant fungi of two different plants (onion and maize). Morphologically, the greater the increase in concentration, the greater the decrease in growth diameter and spore counts of $A$. niger compared to control was found. Physiologically, the total proteins and flavonoids of mutant $A$. niger decreased compared to control. The $\mathrm{pH}$ of the medium was not significantly affected by the growth of mutant fungi. At the molecular level, there was genetic variation in the genetic content of mutant fungi compared to control. RAPD-PCR molecular marker analysis resulted in a polymorphism percentage of $78.56 \%$. The second part of the study explained that the greater the increase in mutant concentration, the greater was the increase in the physiological activity of the plants which were treated with these fungi. The innovative aspect of using $A$. niger in this study, was to apply the chemical mutation to infect the fungus, then to compare the effect of mutant fungi on essential crops, compared to control infection. To sum up, sodium azide inhibits fungal activity and enhances plant resistance.

Author Contributions: Conceptualization, E.T., M.A., S.A., A.A. and E.F.; methodology, E.T.; software, E.T.; validation, E.T.; formal analysis, E.T.; investigation, E.T.; resources, E.T., M.A., S.A., A.A., E.F. and L.B.; data curation, E.T.; writing-original draft preparation, E.T.; writing-review and editing, E.T.; visualization, E.T., M.A., S.A. and A.A. All authors have read and agreed to the published version of the manuscript.

Funding: This research received no external funding.

Institutional Review Board Statement: Not applicable.

Informed Consent Statement: Not applicable.

Data Availability Statement: Not applicable.

Acknowledgments: The authors are grateful to both the Faculty of Science, Helwan University, Egypt and the Faculty of Sciences, Taif University, Saudi Arabia for providing support for working materials.

Conflicts of Interest: The authors declare no conflict of interest.

\section{References}

1. Schuster, E.; Dunn-Coleman, N.; Frisvad, J.C.; van Dijck, P.W.M. On the safety of Aspergillus niger-A review. Appl. Microbiol. Biotechnol. 2002, 59, 426-435. [PubMed]

2. Blumenthal, C.Z. Production of toxic metabolites in Aspergillus niger, Aspergillus oryzae, and Trichoderma reesei: Justification of mycotoxin testing in food grade enzyme preparations derived from the three fungi. Regul. Toxicol. Pharmacol. 2004, 39, 214-228. [CrossRef] [PubMed]

3. Shankar, J. An Overview of Toxins in Aspergillus Associated with Pathogenesis. Int. J. Life Sci. Bt. Pharm. Res. $2013,2,16-31$.

4. Cortesão, M.; de Haas, A.; Unterbusch, R.; Fujimori, A.; Schütze, T.; Meyer, V.; Moeller, R. Aspergillus niger Spores Are Highly Resistant to Space Radiation. Front. Microbiol. 2020, 11, 560. [CrossRef]

5. Madika, A.; Ulem, E.A.; Musa, B.; Sulaiman, M.A.; Hussaini, I.M. Screening of Aspergillus Niger Isolated from Soil for Pectinase Production. FUDMA J. Sci. 2020, 4, 244-249. [CrossRef]

6. $\quad$ El-Nagerabi, S.A.F.; Ahmed, A.H.M.; Elshafie, A.E. In Vitro Evaluation of Selected Plant Extracts as Biocontrol Agents against Black Mold (Aspergillus niger Van Tieghem) of Onion Bulbs (Allium Cepa L.). Int. J. Sci. Technol. Res. 2016, 5, 147-152.

7. Zohri, A.; Boul-Nasr, M.B.; Adam, M.; Mustafa, M.A.; Amer, E.M. Impact of Enzymes and Toxins Potentiality of Four Aspergillus Species to Cause Aspergillosis. Biol. Med. 2017, 9, 1-7. 
8. El-Mokadem, H.E.; Mostafa, G.G. Induction of mutations in Browallia speciosa using sodium azide and identification of the genetic variation by peroxidase isozyme. Afr. J. Biotechnol. 2014, 13, 106-111. [CrossRef]

9. Grant, W.F.; Salamone, M.F. Comparative mutagenicity of chemicals selected for test in the International Program on Chemical Safety's collaborative study on plant systems for the detection of environmental mutagens. Mutagenesis Res. 1994, 310, 187-209. [CrossRef]

10. Hussain, M.; Gul, M.; Kamal, R.; Iqbal, M.A.; Zulfiqar, S.; Abbas, A.; Röder, M.S.; Muqaddasi, Q.H.; Mehboob-ur-Rahman. Prospects of Developing Novel Genetic Resources by Chemical and Physical Mutagenesis to Enlarge the Genetic Window in Bread Wheat Varieties. Agriculture 2021, 11, 621. [CrossRef]

11. White, T.J.; Bruns, T.; Lee, S.; Taylor, J. Amplification and direct sequencing of fungal ribosomal RNA genes for phylogenetics. In PCR Protocols: A Guide to Methods and Applications; Innis, M.A., Gelfand, D.H., Sninsky, J.J., White, T.J., Eds.; Academic Press: London, UK, 1990; Volume 18, pp. 315-322.

12. Suprasanna, P.; Mirajkar, S.J.; Bhagwat, S.G. Induced Mutations and Crop Improvement. Plant. Biol. Biotechnol. 2015, 1, 593-617.

13. Bradford, M.M. A Rapid and Sensitive Method for the Quantitation of Microgram Quantities of Protein Utilizing the Principle of Protein-Dye Binding. Anal. Biochem. 1976, 72, 248-254. [CrossRef]

14. Tawfik, E.; Fathy, M. Chemical Mutagens Affecting in vitro Behavior of Gardenia jasminoides. Plant Tissue Cult. Biotechnol. 2020, 30, 209-218. [CrossRef]

15. Zhishen, J.; Mengcheng, T.; Jianming, W. The determination of flavonoid contents in mulberry and their scavenging effects on superoxide radicals. Food Chem. 1999, 64, 555-559. [CrossRef]

16. Doyle, J.J.; Doyle, J.L. Isolation of Plant DNA from Fresh Tissue. Focus 1990, 12, $13-15$.

17. Shuaib, M.; Zeb, A.; Ali, Z.; Ali, W.; Ahmad, T.; Khan, I. Characterization of Wheat Varieties by Seed Storage Protein Electrophoresis. Afr. J. Biotechnol. 2007, 6, 497-500.

18. Romsdahl, J.; Blachowicz, A.; Chiang, A.J.; Singh, N.; Stajich, J.E.; Kalkum, M.; Venkateswaran, K.; Wanga, C.C.C. Characterization of Aspergillus niger Isolated from the International Space Station. mSystems 2018, 3, e00112-18. [CrossRef]

19. Soares, C.; Calado, T.; Venâncio, A. Mycotoxin production by Aspergillus niger aggregate strains isolated from harvested maize in three Portuguese regions. Rev. Iberoam. Micol. 2012, 30, 9-13. [CrossRef]

20. Freire, L.; Guerreiro, T.M.; Pia, A.K.R.; Lima, E.O.; Oliveira, D.N.; Melo, C.F.O.R.; Catharino, R.R.; Sant'ana, A.S. A quantitative study on growth variability and production of ochratoxin A and its derivatives by $A$. carbonarius and $A$. niger in grapebased medium. Sci. Rep. 2018, 8, 14573. [CrossRef]

21. Dijksterhuis, J.; Samson, R.A. Food and crop spoilage on storage. In Mycota X1 Agricultural Applications; Kemken, F., Ed.; Springer: Berlin/Heidelberg, Germany, 2002; pp. 39-52.

22. Kumar, A.K.; Parikh, B.S. Cellulose-degrading enzymes from Aspergillus terreus D34 and enzymatic saccharification of mild-alkali and dilute-acid pretreated lignocellulosic biomass residues. Bioresour 2015, 2, 7. [CrossRef]

23. Ramachandran, S. Mise en oeuvre des spores $\mathrm{d}^{\prime}$ Aspergillus niger obtenues par fermentation en milieu solide pour la production $\mathrm{d}^{\prime}$ acide gluconique (Use of spores of Aspergillus niger obtained by Solid-state fermentation for the production of gluconic acid). In Génie Des Proceeds; Université Blaise Pascal-Clermont-Ferrand II: Clermont-Ferrand, France, 2008.

24. Vernwal, S.K.; Yadav, R.S.; Yadav, K.D. Purification of a peroxidase from Solanum melongena fruit juice. Indian J. Biochem. Biophys. 2006, 43, 239-243. [PubMed]

25. Lu, L.; Zhao, M.; Zhang, B.B.; Yu, S.Y.; Bian, X.J.; Wang, W.; Wang, Y. Purification and characterization of laccase from Pycnoporus sanguineus and decolorization of an anthraquinone dye by the enzyme. Appl. Microbiol. Biotechnol. 2007, 74, 1232-1239. [CrossRef] [PubMed]

26. Gromada, A.; Fiedurek, J. Selective isolation of Aspergillus niger mutants with enhanced glucose oxidase production. J. Appl. Microbiol. 1997, 82, 648-652. [CrossRef]

27. Lucca, A.L.; Jorge, J.A.; Guimaraes, L.H.S. Extracellular $\beta$-D-fructofuranosidase from Aspergillus parasiticus: Optimization of the production under submerged fermentation and biochemical characterization. Afr. J. Biotechnol. 2013, $12,5678-5687$.

28. Salaman, Z.A.; Abdulmalek, H.W.; Al-Judy, N.J.; Dheeb, B.I.; Al Abbasi, S.H.A. Detection the ability of Aspergillus parasiticus local Iraqi isolates for aflatoxin B1 production. Curr. Res. Microbiol. Biotechnol. 2015, 3, 564-568.

29. Youssef, M.S.; El-Maghraby, O.M.O.; Ibrahim, Y.M. Mycobiota and mycotoxins of Egyptian peanut (Arachis hypogeae L.) seeds. Int. J. Bot. 2008, 4, 349-360. [CrossRef]

30. Costa, R.; Pereira, G.; Garrido, I.; Tavares-de-Sousa, M.M.; Espinosa, F. Comparison of RAPD, ISSR, and AFLP molecular markers to reveal and classify Orchardgrass (Dactylis glomerata L.) germplasm variations. PLoS ONE 2016, 11, e0152972. [CrossRef] [PubMed]

31. Longya, A.; Chaipanya, C.; Franceschetti, M.; Maidment, H.R.J.; Banfield, J.M.; Jantasuriyarat, C. Gene duplication and mutation in the emergence of a novel aggressive allele of the AVR-Pik effector in the rice blast fungus. Mol. Plant Microbe Interact. 2019, 32, 740-749. [CrossRef]

32. Longya, A.; Talumphai, S.; Jantasuriyarat, C. Morphological Characterization and Genetic Diversity of Rice Blast Fungus, Pyricularia oryzae, from Thailand Using ISSR and SRAP Markers. J. Fungi 2020, 6, 38. [CrossRef]

33. Flaherty, J.E.; Payne, G.A. Overexpression of aflR leads to upregulation of pathway gene transcription and increased aflatoxin production in Aspergillus flavus. Appl. Environ. Microbiol. 1997, 63, 3995-4000. [CrossRef] 
34. McDonald, B.A.; Linde, C. Pathogen population genetics, evolutionary potential, and durable resistance. Annu. Rev. Phytopathol. 2002, 40, 349-379. [CrossRef] [PubMed]

35. Çelik, O.; Oguz, A.; Karakaya, A. Genetic Diversity of Barley Foliar Fungal Pathogens. Agronomy 2021, 11, 434. [CrossRef]

36. Sowley, E.; Kankam, F.; Tawiah, E. Comparative Study on the Incidence of Aspergillus flavus in Farmer's Field and Stored Maize (Zea mays) Seed in Northern Region of Ghana. Asian J. Plant Sci. 2018, 1, 1-7. [CrossRef]

37. Subramanian, S.; Kiarie, S.; Kiarie, S.; Nyasani, J.; Nyasani, J.; Gahole, L. Impact of Fungal Endophyte Colonization of Maize (Zea mays L.) on Induced Resistance to Thrips- and Aphid-Transmitted Viruses. Plants 2020, 9, 416. [CrossRef] 